\title{
Influence of the capuchin hydroethanolic extract (Tropaeolum majus L.) on the stability of ketoconazole
}

\author{
Ana Merian da Silva ${ }^{1}$ (D), Lucélia Magalhães da Silva* \\ ${ }^{1}$ Curso de Farmácia, Instituto Federal do Paraná (IFPR), Palmas, PR, Brasil \\ *Corresponding author: lucelia.silva@ifpr.edu.br
}

\begin{abstract}
The stability of pharmaceuticals is influenced by several factors, directly related to the product, or to environmental factors, such as the presence of light and oxygen. Ketoconazole is an antifungal drug of the azole class that is prone to degradation processes, such as oxidation and hydrolysis, changing from white to pink, suggesting the formation of degradation products. Capuchin (Tropaeolum majus L.) is a species of pharmacological interest due to its phytochemical composition; it is rich in vitamin C and flavonoids with known antioxidant activity. The objective of this work was to investigate the antioxidant activity of capuchin hydroethanolic extracts and evaluate their influence on the stability of ketoconazole. For the evaluation of the antioxidant activity of the extracts, the DPPH radical was used. Different ketoconazole gel formulations were manipulated and subjected to a stability study to compare the antioxidant efficiency of the extract and sodium metabisulphite by analyzing the samples by ultraviolet scanning. Microbiological assays were performed to evaluate the activity of ketoconazole against the fungus Candida albicans. The extract solution presented antioxidant activity equivalent to a $12.71 \mu \mathrm{g} / \mathrm{mL}$ metabisulfite solution, and a $0.085 \mu \mathrm{g}$ metabisulfite/ $\mu \mathrm{g}$ extract ratio was calculated. In the spectrophotometric analysis, it was observed that the absorption spectrum of the extractcontaining formulation presented differently from the others, with a possible advantage in relation to the synthetic antioxidant. In the microbiological analysis, only the samples that remained at room temperature formed an inhibition halo. Thus, the potential of a natural active was evaluated, representing a possible alternative for application in pharmaceutical formulations.
\end{abstract}

Keywords: Capuchin. Antioxidant Activity. Stability. Natural Active.

\section{How to cite}

Silva AM, Silva LM. Influence of the capuchin hydroethanolic extract (Tropaeolum majus L.) on the stability of ketoconazole. Rev Ciênc Farm Básica Apl. 2020;41:e679. https://doi.org/10.4322/2179443X.0679

\section{INTRODUCTION}

The stability of pharmaceuticals is influenced by several factors which may be directly related to the product, such as its physicochemical properties, or environmental factors (Brasil, 2005). Light and oxygen directly interfere with the stability of substances because they form free radicals that give rise to oxidation-reduction reactions, causing changes in the active substances. These products should primarily be stored in low light environments and with the addition of antioxidants (Brasil, 2004; Silva et al., 2017). 
Some stability problems are observed in formulations with the drug ketoconazole. It is an antifungal drug with a mechanism of action that basically consists of inhibiting ergosterol biosynthesis, an essential component for the integrity of the fungal cell membrane. Its broad spectrum of action allows it to be used in superficial and systemic infections, for example the fungus Candida albicans (Rubim et al., 2012; Castro et al., 2016).

The most commonly used topical dosage forms of ketoconazole are shampoos, creams and ointments, requiring regular application to the skin for effective treatment. Ketoconazole may present solubility problems, depending strongly on $\mathrm{pH}$ for solubilization in an aqueous medium (Azevedo \& Falcão, 2018), which can lead to drug degradation processes, such as oxidation and hydrolysis. In aqueous acid medium, there is a color change from white to pink, suggesting the formation of degradation products as a consequence of factors that the product has been exposed to (Duque et al., 2013; Staub et al., 2007).

In this context, research interest in new antioxidants has grown in recent times, leading the food, cosmetics and pharmaceutical industries to focus more attention on new sources, especially those with a natural origin. The antioxidants of vegetables are highly varied; however, phenolic compounds have been identified as being responsible for the antioxidant capacity, represented by flavonoids and isoflavonoids, among others (Razavi et al., 2008).

Tropaeolum majus L., commonly known capuchin, is a plant belonging to the family Tropaeolaceae. It is easily cultivated and considered an unconventional food plant (PANC), as it is possible to ingest its leaves, flowers and stalks, which are rich in phenolic compounds, minerals and micronutrients such as vitamin C (Silva et al., 2018). The red capuchin flower presents the highest fresh vitamin C content $(129 \mathrm{mg} / 100 \mathrm{~g})$, which is higher than in many citrus fruits such as lemon ( $55 \mathrm{mg} / 100 \mathrm{~g}$ ) and orange (57 mg/100 g) (Fernandes et al., 2016).

In a phytochemical study of $T$. majus extracts, the presence of several components was confirmed, such as the flavonoids quercetin and isoquercetin, responsible for the extract's antioxidant activity (Lourenço et al., 2012). Another component is benzyl isothiocyanate, which gives the plant antiinflammatory activity (Aguilar-Villanueva et al., 2017). Other activities are antifungal and antibacterial (Brondani et al., 2016). Thus, the objective of this work was to investigate the antioxidant activity of capuchin hydroethanolic extracts and to evaluate their capacity to improve the stability of easily oxidizable drugs such as ketoconazole, submitted to oxidative stress conditions.

\section{METHODOLOGY}

Inputs

The following inputs were used: propylene glycol (Alphatec - lot: 25240); propylparaben (Vetec-lot: 0504589); disodium edta (F. Maia - lot: 33286); absolute ethyl alcohol (Alphatec - lot: 25806); methyl alcohol P.A (Dynamic - batch: 77677); hydroxyethylcellulose (Purifarma - Lot: VD2631V5H1); sorbitol (Tate \& Lyle - Lot: 99910); methylparaben (Dynamic - batch: 102030); imidazolidinylurea (Mix das Essências LTDA) and DPPH reagent (Interprise Instrumentos Analíticos LTDA); ketoconazole (NR 148877).

\section{Botanical material}

The leaves of Tropaeolum majus L. (Capuchin) were collected in the Palmas, Paraná. They were dried in an oven with air circulation at $35^{\circ} \mathrm{C}$ for 3 days. The botanical identification was performed by preparation of exsicata and sending to the Municipal Botanical Garden of Curitiba, PR, deposited under the number MBM 411211.

\section{Preparation of extracts}

To prepare the extracts, the capuchin leaves were crushed in a multiprocessor and the extraction was carried out by maceration using water and ethanol as solvents. The extracts were prepared in the ratio 1:10 (plant: solvent $p / p$ ) using ethanol solutions in the 
concentrations of $50 \%, 70 \%$ and $100 \%$. The extracts were stored in amber glass vials, shaken daily for 15 days, followed by vacuum filtration and solvent removal by a rotavaporation system at $50^{\circ} \mathrm{C}$ and an oven at $40^{\circ} \mathrm{C}$.

\section{Determination of antioxidant activity (DPPH)}

The antioxidant activity evaluation employed 2.2-diphenyl-1-picrylhydrazyl (DPPH), which is a radical with a free electron; it basically consists of quantifying the ability of a substance to sequester the DPPH radical, with a violet coloration, and reduce it to hydrazine, which has a pale yellow coloration. The violet coloration in alcoholic solution has a band of maximum absorption at the wavelength of $517 \mathrm{~nm}$ (Alves et al., 2010).

To evaluate the antioxidant activity of the samples, the synthetic antioxidant sodium metabisulphite was used, determined by the free radical DPPH (2,2-diphenyl-1-picrylhydrazyl) described by Lange et al. (2009), with adaptations. The DPPH solution was prepared in methanol at a concentration of $0.00013 \mathrm{M}$. For the preparation of the metabisulfite solution, $0.05 \mathrm{~g}$ was weighed and transferred to a $25 \mathrm{~mL}$ volumetric flask, then the volume was quenched with methanol. From this solution, other solutions were prepared at concentrations of $0.6 \mu \mathrm{g} / \mathrm{mL}, 3 \mu \mathrm{g} / \mathrm{mL}, 12 \mu \mathrm{g} / \mathrm{ml}, 24 \mu \mathrm{g} / \mathrm{mL}$ and $36 \mu \mathrm{g} / \mathrm{mL}$. To the extracts, $1 \mathrm{~mL}$ of concentrated extract was transferred into a $10 \mathrm{~mL}$ volumetric flask, then the volume was made up with methanol. Next, $0.1 \mathrm{~mL}$ of this solution was transferred to a $50 \mathrm{~mL}$ flask, and the volume was made up with methanol. Finally, $3 \mathrm{~mL}$ of each dilution was withdrawn and transferred to a test tube containing $1 \mathrm{ml}$ of DPPH solution, and protected from light for 30 minutes. The control solution was prepared with $3 \mathrm{~mL}$ of methanol and $1 \mathrm{~mL}$ of DPPH solution. Afterwards, the samples were read at $517 \mathrm{~nm}$. All assays were performed in triplicate.

For the evaluation of free radical capture activity, the percentage of DPPH inhibition was calculated according to the Equation 1:

$\%$ inhibition of $D P P H=[(A 0-A 1) / A 0 \times 100]$

where: $\mathrm{A} 0$ is the absorbance of the control and $\mathrm{A} 1$ is the absorbance of the sample.

\section{Manipulation of the pharmaceutical formulation}

Manipulation of the hydroxyethylcellulose gel was performed according to the protocol established by Brazilian Pharmacopoeia (Brasil, 2012), described in Table 1. The formulation consisted of the addition of ketoconazole at a concentration of $2 \%$. For manipulation, the components of phase A were mixed and added to the components of phase B under slow stirring. Thereafter, the $\mathrm{C}$ phase components were added to the respective formulations.

Table 1 - Preparation of the hydroxyethyl cellulose gel to evaluate the antioxidant activity of the extract.

\begin{tabular}{|c|c|c|c|c|c|}
\hline Phases & Element & $\begin{array}{l}\text { Amount } \\
(\% \mathrm{p} / \mathrm{p})\end{array}$ & Base Gel & $\begin{array}{c}\text { Gel + } \\
\text { metabisulfite }\end{array}$ & Gel + extract \\
\hline \multirow[t]{3}{*}{ A } & hydroxyethylcellulose & $2.5 \mathrm{~g}$ & $x$ & $\mathrm{x}$ & $x$ \\
\hline & sorbitol & $3 \mathrm{~g}$ & $x$ & $x$ & $x$ \\
\hline & distilled water & qsp 100 & $x$ & $x$ & $x$ \\
\hline \multirow[t]{3}{*}{ B } & edetate disodium & $0.1 \mathrm{~g}$ & $x$ & $x$ & $x$ \\
\hline & parabens preservative solution & $3.3 \mathrm{~g}$ & $x$ & $x$ & $x$ \\
\hline & $\begin{array}{c}\text { imidazolidinylurea preservative } \\
\text { solution }\end{array}$ & $0.6 \mathrm{~g}$ & $x$ & $x$ & $x$ \\
\hline \multirow[t]{3}{*}{ C } & $\begin{array}{l}\text { hydroethanolic extract (ethanol } \\
50 \% \text { ) }\end{array}$ & $10 \%$ & & & $x$ \\
\hline & sodium metabisulfite & $0.2 \%$ & & $x$ & \\
\hline & ketoconazole & $2 \%$ & $x$ & $x$ & $x$ \\
\hline
\end{tabular}




\section{Evaluation of the stability of ketoconazole in the absence and presence of antioxidants}

To compare the antioxidant efficiency of the extract and the synthetic antioxidant sodium metabisulfite, the gel samples were packed in transparent containers and stored in an oven at $40^{\circ} \mathrm{C}$ with a fluorescent lamp. In parallel, as a control, each sample was stored at room temperature and protected from light. The samples were analyzed by ultraviolet spectrophotometry scanning in the range of 200 to $400 \mathrm{~nm}$ on the day of preparation and after 20 days. The gel formulation containing all components of each sample, except ketoconazole, was adopted as the blank. For the readings, the samples were diluted to a concentration of $0.001 \mathrm{~g} / \mathrm{mL}$, using $0.1 \mathrm{M}$ hydrochloric acid $(\mathrm{HCl})$ as the solvent. The samples were also analyzed for their organoleptic characteristics at the time of preparation and after the storage period.

\section{Disk method - diffusion in agar}

\section{Preparation of the inoculum}

First, all materials used were autoclaved. The microorganism Candida albicans (ATCC 10231) was inoculated into a tube containing $10 \mathrm{~mL}$ of Brain Heart Infusion (BHI) broth and incubated in an oven (Biopar) at $37^{\circ} \mathrm{C}$ for 24 hours. At the time of the assay, the inoculum was adjusted in saline solution for $25 \%$ transmittance at $580 \mathrm{~nm}$ (Brasil, 2010).

\section{Preparation of the samples}

The solutions of the gel samples were prepared by weighing $1 \mathrm{~g}$ of sample, which was transferred to a $10 \mathrm{~mL}$ volumetric flask, then dissolved and quenched with $0.1 \mathrm{M} \mathrm{HCl}$. Next, $2 \mathrm{~mL}$ was transferred to a $10 \mathrm{~mL}$ flask, and the volume was made up with phosphate buffer ( $\mathrm{pH}$ 6.0). Then, $50 \mu \mathrm{L}$ of the solution was applied to $5 \mathrm{~mm}$ filter paper disks. All assays were performed in triplicate.

\section{Test}

The method used was described by Diogo et al. (2010) with adaptations. A volume of $20 \mathrm{~mL}$ of Sabouraud agar dextrose culture medium was added to Petri dishes. After complete solidification, the standardized inoculum was uniformly distributed throughout the surface with a Drigalski loop. The paper disks containing the samples were placed on the inoculated medium, distributed in order not to have overlap of the inhibition halos. After an incubation period of 48 hours at $37^{\circ} \mathrm{C}$, the halos were measured.

\section{Ethics statement}

In the present research there were no studies with humans or animals.

\section{RESULTS}

In the analysis of the antioxidant activity of the capuchin extracts, the equation described in the methodology was used to determine the percentage of inhibition of DPPH; the results are shown in Table 2. To compare the antioxidant activity of the capuchin extract with the synthetic antioxidant metabisulfite, the \% inhibition curve of DPPH according to the concentration of the antioxidant was constructed (Figure 1). 


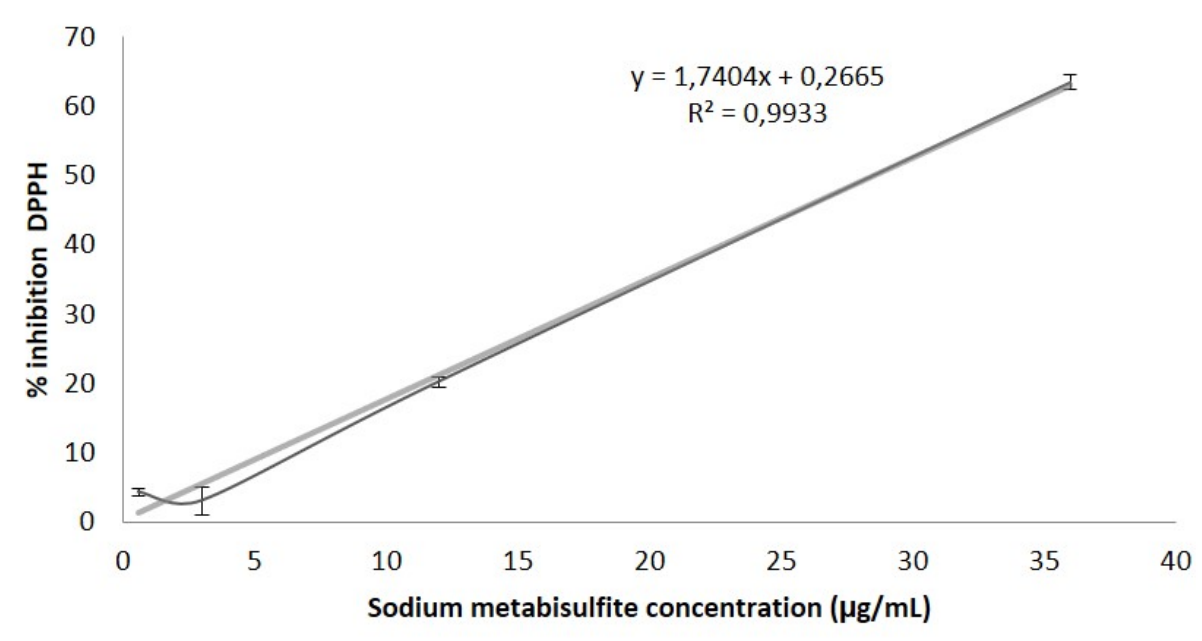

Figure 1 - Relationship between sodium metabisulfite concentration and percent inhibition of DPPH radical.

Table 2. Values of antioxidant activity by reduction of the DPPH radical of each extract in triplicate and sodium metabisulfite equivalence per $\mu \mathrm{g}$ of sample.

\begin{tabular}{ccc}
\hline $\begin{array}{c}\text { Extract } \\
\text { (alcohol/water v/v) }\end{array}$ & \% inhibition of DPPH & $\begin{array}{c}\text { Equivalence } \mu \text { g metabisulphite/ } \\
\mu g \text { sample } \pm \text { SD* }\end{array}$ \\
\hline $\mathbf{5 0 / 5 0}$ & $\mathbf{2 2 . 3 9}$ & $0.108 \pm 0.0034$ \\
$\mathbf{7 0 / 3 0}$ & $\mathbf{4 . 8 8}$ & $0.032 \pm 0.0065$ \\
$\mathbf{1 0 0}$ & $\mathbf{4 . 7 1}$ & $0.030 \pm 0.0045$ \\
\hline
\end{tabular}

* SD: standard deviation.

When analyzing the data in the Table 2, it was observed that all the extracts had antioxidant activity; however the extracts with $70 \%$ and $100 \%$ ethanol showed results inferior to the $50 \%$ extract.

The equation of the line of Figure 1 allowed us to perform a comparison of the antioxidant activities of the extract and of the metabisulfite, with the extract solution equivalent to a 12.71 $\mu \mathrm{g} / \mathrm{mL}$ metabisulfite solution. Additionally, the ratio between the mass of the extract and metabisulphite was calculated, which was $0.085 \mu \mathrm{g}$ of metabisulphite/ $\mu \mathrm{g}$ of extract.

\section{Assessment of the stability of ketoconazole}

In order to test for the possible antioxidant activity of the extract on the drug in a pharmaceutical formulation, the extract was combined in a gel containing ketoconazole. A spectrophotometric scan was performed to evaluate the ketoconazole content, as can be observed in Figure 2.

The formulations containing the extract showed characteristic staining, indicating that there is an influence of the extract on the color of the formulation. The metabisulfite gel showed a slightly pinkish coloration, while the antioxidant-free formulation had a strong pink coloration, possibly due to drug degradation. In relation to the other characteristics, all presented themselves according to the specifications. In this context, the ultraviolet absorption profiles of the samples at different times of the stability study and with different antioxidants were constructed to visualize possible alterations. As can be seen in Figure 2, the absorption spectrum of the extractcontaining formulation presented a different change from that observed in the other formulations, thus presenting a possible advantage over the synthetic metabisulfite antioxidant in protecting ketoconazole from degradation. 

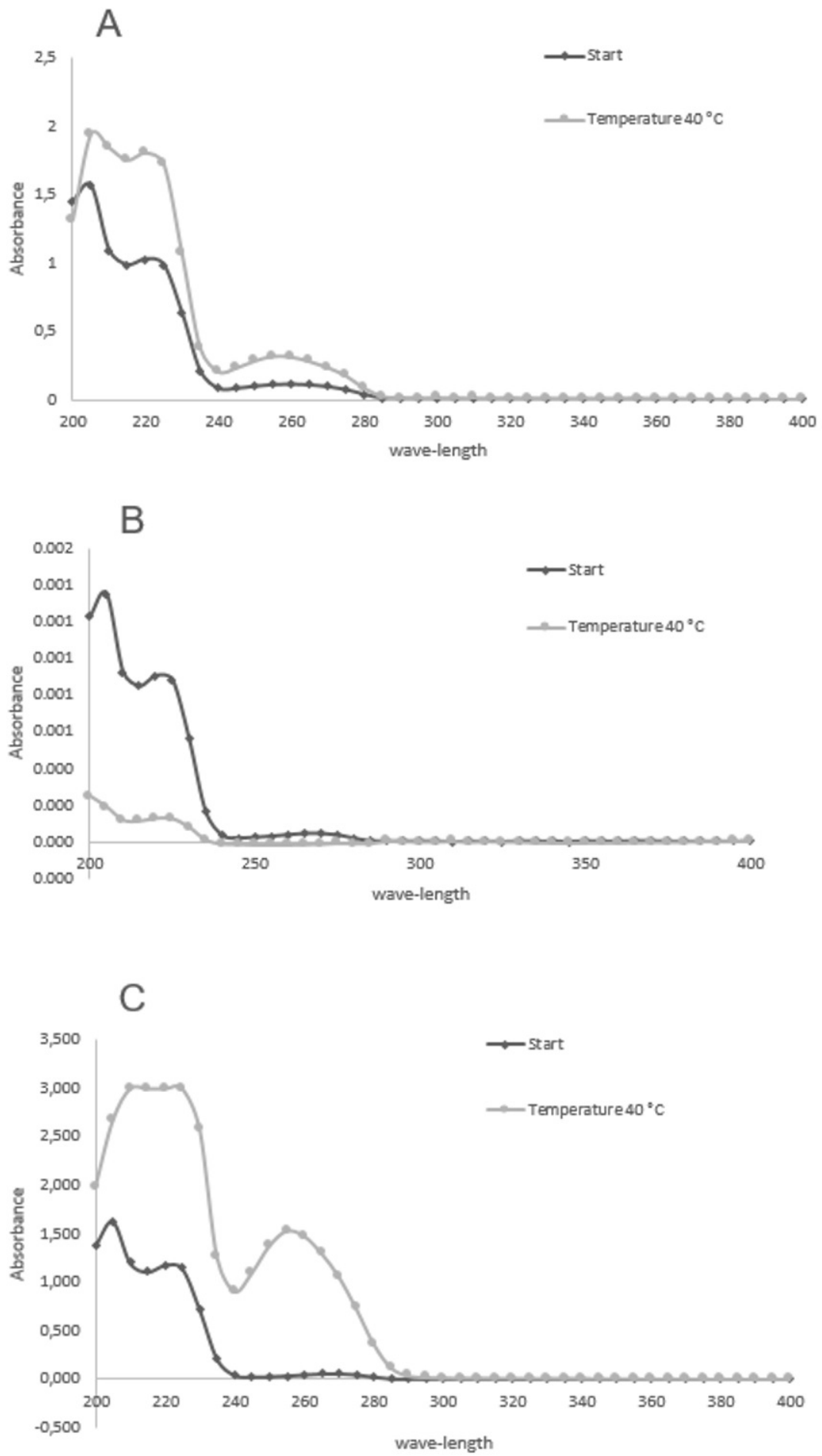

Figure 2 - Evaluation of the stability of ketoconazole in the different formulations: A - gel with ketoconazole and sodium metabisulfite, B - gel with ketoconazole and extract and C - gel and ketoconazole.

\section{Microbiological evaluation}

Table 3 presents the results of the microbiological analyses by the evaluation of the inhibition halos formed by the formulations of gels A, B and C. The measurement of the halos of the samples containing the extract was superior compared to the other samples and could be indicative of the antifungal action of the extract and/or a possible synergism between the plant extract and ketoconazole, potentializing its effect. 
Table 3. Evaluation of the antifungal activity of the formulations containing ketoconazole

\begin{tabular}{cc}
\hline Samples & Inhibition halos (cm) \pm SD * \\
\hline Gel + ketoconazole + metabisulfite & $2.33 \pm 0.29$ \\
Gel + ketoconazole + extract & $3.0 \pm 0.00$ \\
Gel + ketoconazole & $2.83 \pm 0.29$ \\
\hline
\end{tabular}

* SD: standard deviation.

\section{DISCUSSION}

\section{Evaluation of antioxidant activity}

The antioxidant activity of the extract can be explained mainly by the presence of several bioactive compounds present in the plant, such as flavonoids (quercetin and isoquercetin) that constitute an important class of polyphenols, in addition to fatty acids (oleic and linoleic), vitamin C and benzylisothiocyanates (Bazylko et al., 2013). In this context, some studies describing the phytochemical profile of $T$. majus leaves have pointed out the presence of fatty acids, such as erucic acid, oleic and linoleic acid and also the presence of glucosinolates and flavonoids, giving prominence to isoquercetin, quercetin and kaempferol as being responsible for the antioxidant activity. Thus, this plant may be interesting to use as a component of pharmaceutical/cosmetic formulations (Simões et al., 2017; Correa et al., 2016).

Bazylko et al. (2014) determined the antioxidant activity by DPPH of T. majus by analysis of the aqueous extract, hydroethanolic extract and leaf juice. At a concentration of $100 \mu \mathrm{g} / \mathrm{mL}$, the hydroethanolic extract presented the best result of inhibition of the radical, at 37.5\%, followed by the juice at $34.7 \%$ and the aqueous extract at $24.1 \%$. In another test for the elimination of the DPPH radical, the ethanolic and aqueous extracts had an elimination capacity of $52.5 \%$ and $66.1 \%$, respectively (Valsalam et al., 2019).

Considering that the antioxidant evaluation by the DPPH method indicates the ability to eliminate free radicals (Wu et al., 2011), the capuchin properties described in the literature were confirmed with the results obtained in this study. The extract showed an activity comparable to synthetic antioxidants, demonstrating its high potential as a possible natural asset; however, further studies are necessary to isolate and determine the bioactive chemical substances in T. majus extract.

To measure ketoconazole in different formulations, several analytical procedures can be performed, such as titrometric, spectrophotometric and chromatographic methods (Proença et al., 2007). In this work, a spectrophotometric method was used to evaluate the influence of the antioxidant used on ketoconazole stability. The formulations were evaluated at pre-established times to verify if there were changes in the drug content. However, there are situations in which the degradation products interfere in the quantification of the drug, as there may also be overlap of absorption bands in spectrophotometer readings in the UV-vis region of samples with many analytes, leading to false negative results. Thus, oxidation may be visible, but cannot be quantified, since the content of the analyte remains, or even increases over time (Paschoal et al., 2003).

Staub (2005) determined the stability of $2 \%$ ketoconazole in shampoo exposed to visible light for five days. The assay performed in the UV region detected changes in the initial and final formulations. Furthermore, a second test evaluated the incorporation of antioxidants (vitamin E and BHT) and their ability to promote the stability of ketoconazole creams and shampoos. The samples were placed at different temperatures and evaluated by spectrophotometry in the UV region in an established period of time. The samples stored at low temperatures did not present the same alteration compared to samples kept at room temperature, demonstrating the importance of antioxidants in the formulations.

In this way, it is possible to detect sample degradation processes by comparing the absorption spectra before and after some degradation process (Pavia et al., 2010; 
Silverstein et al., 2006). The construction of ultraviolet absorption profiles from the samples can be done at different times of the stability study in order to visualize possible changes. As can be seen in Figure 2, graphs $\mathrm{A}$ and $\mathrm{C}$ showed similar absorption profiles, with an increase in the absorbance of ketoconazole compared to the initial time, suggesting the presence of degradation products from oxidation. However, in formulation $B$, there was a different degradation pathway, since there was no such increase in absorbance, indicating that the extract altered or prevented the oxidation of ketoconazole, although it did not prevent the decrease in its content.

Additionally, based on literature data on Tropaeolum majus L. antifungal activity, microbiological power tests were performed, using Candida albicans as a biological marker, since this microorganism is sensitive to ketoconazole. Aguilar-Villanueva et al. (2017) tested the in vivo effect of $T$. majus ethanolic extract on Trichophyton mentagrophytes-induced mycoses in rats. The extract presented antimycotic activity at a concentration of $0.4 \%$. Among the substances present in the plant with possible antifungal activity, benzyl isothiocyanate and glucotropaeolin have bacteriostatic and fungistatic activity (Lourenço et al., 2012). A second study on the antimicrobial activity of $T$. majus hydroethanolic extracts showed activity against Staphylococcus aureus and Escherichia coli, explaining that both solvents have the capacity to extract phenolic and antimicrobial compounds, taking into account the chain of each compound and the connections that can be formed with water and alcohol (Albinagorta \& Leon Robladillo, 2015).

In this study, the extract formulation obtained greater inhibition halos when compared to the other formulations, in agreement with the reports on the antifungal activity of capuchin extract. Thus, it can be concluded that extracts of $T$. majus have significant antioxidant activity, and are of great importance when it comes to the investigation of new bioactive substances. Moreover, based on the results of the stability test of ketoconazole associated with the T. majus extract, it is inferred that the extract protected ketoconazole from oxidation degradation. It should be emphasized that complementary studies should be carried out in order to verify possible synergism with ketoconazole's antifungal activity, as well as possible in vivo reactions of this extract.

\section{ACKNOWLEDGMENTS:}

To Mr. Marcelo Brotto, of the Municipal Botanical Museum of Curitiba, for kindly having performed the botanical identification of the species used.

\section{REFERENCES}

Aguilar-Villanueva DA, Avalos-Murga SP, Rojas-Plasencia P, Marquillo-Bartra I, Ayala-Ravelo MS. Efecto del extracto etanólico de Tropaeolum majus "mastuerzo" sobre la micosis inducida por Trichophyton mentagrophytes en Rattus norvegicus. Acta Méd Peruana. 2017;3(34):196-202. http://dx.doi.org/10.35663/amp.2017.343.403.

Albinagorta LH, Leon Robladillo M. Evaluación de la actividad antimicrobiana de los extractos metanólicos de las hojas y flores de la especie vegetal Mastuerzo (Tropaeolum majus L.) frente al crecimiento de microorganismos (Escherichia coli y Staphylococcus aureus) [tese]. Perú: Faculdade de Engenharia em Indústria Alimentícia, Universidad Nacional Del Centro Del Caribe; 2015.

Alves CQ, David JM, David JP, Bahia MV, Aguiar RM. Métodos para determinação de atividade antioxidante in vitro em substratos orgânicos. Quim Nova. 2010;33(10):2202-10. http://dx.doi.org/10.1590/S0100-40422010001000033.

Azevedo MGB, Falcão JSA. Microemulsão de cetoconazol para incorporação em xampu. Rev. Geintec. 2018;8(1):4271-84. http://dx.doi.org/10.7198/geintec.v8i1.901.

Bazylko A, Granica S, Filipek A, Piwowarski J, Stefanska J, Osinska E, Kiss AK. Comparison of antioxidant, anti-inflammatory, antimicrobial activity and chemical composition of aqueous and hydroethanolic extracts of the herb of Tropaeolum majus L. Ind Crops Prod. 2013;50:88-94.

http://dx.doi.org/10.1016/j.indcrop.2013.07.003. 
Bazylko A, Parzonko A, Jeż W, Osińska E, Kiss AK. Inhibition of ROS production, photoprotection, and total phenolic, flavonoids and ascorbic acid content of fresh herb juice and extracts from the leaves and flowers of Tropaeolum majus. Ind Crops Prod. 2014;55:19-24. http://dx.doi.org/10.1016/j.indcrop.2014.01.056.

Brasil. Agência Nacional de Vigilância Sanitária - ANVISA. Guia de estabilidade de produtos cosméticos. Brasília: ANVISA; 2004. 52 p.

Brasil. Ministério da Saúde. Agência Nacional de Vigilância Sanitária. Resolução nº 1, de 29 de julho de 2005. Guia para a realização de estudos de estabilidade. Diário Oficial da União; Brasília; 1 ago 2005.

Brasil. Ministério da Saúde, Agência Nacional de Vigilância Sanitária. Farmacopeia Brasileira. 5. ed. Vol. 1. Brasília: Ministério da Saúde; 2010.

Brasil. Ministério da Saúde. Agência Nacional de Vigilância Sanitária. Formulário Nacional da Farmacopeia Brasileira. Brasília: Ministério da Saúde; 2012.

Brondani JC, Cuelho CHF, Marangoni LD, Lima R, Guex CG, Bonilha IF, Manfron MP. Traditional usages, botany, phytochemistry, biological activity and toxicology of Tropaeolum majus L. - A review. Bol Latinoam Caribe Plantas Med Aromat. 2016;16(4):264-73.

Castro IMN, Vasconcelos AA Jr, Cunha FA, Cunha MCSO, Menezes EA. Activity comparison of imidazole and triazole antifungals against Candida albicans. Rev. Bras. Anal. Clin. 2016;3(48):216-22.

Correa JS, Monteiro EA, Pavanelli MF, Biazon ACB. Influência do Extrato Hidroetanólico das Folhas de Tropaeolum majus na Restauração Tecidual em Lesões Cutâneas. Rev. Saúde Pesqui. 2016;9(1):1019. http://dx.doi.org/10.17765/1983-1870.2016v9n1p101-109.

Diogo HC, Melhem M, Sarpieri A, Pires MC. Avaliação do método de disco-difusão para determinação da eficácia da terbinafina in vitro em agentes de micoses superficiais e subcutâneas. An Bras Dermatol. 2010;85(3):324-30. http://dx.doi.org/10.1590/S0365-05962010000300005. PMid:20676465.

Duque MD, Souza DH, Gonçalves LM, Bernardo RS, Pinho JJRG. Avaliação das propriedades físicoquímicas de preparações farmacêuticas contendo cetoconazol para uso tópico. HU Revista. 2013;39(3-4):45-9.

Fernandes L, Casal S, Pereira JA, Saraiva JA, Ramalhoa E. Uma perspetiva nutricional sobre flores comestíveis. Acta Port. Nutr. 2016;6:32-7. http://dx.doi.org/10.21011/apn.2016.0606.

Lange MK, Heberlé G, Milão D. Avaliação da estabilidade e atividade antioxidante de uma emulsão base não-iônica contendo resveratrol. Braz J Pharm Sci. 2009;45(1):145-51. http://dx.doi.org/10.1590/S1984-82502009000100018.

Lourenço EL, Muller JC, Boareto AC, Gomes C, Lourenço AC, Minatovicz B, Crestani S, Gasparotto A Jr, Martino-Andrade AJ, Dalsenter PR. Screening for in vivo (anti) estrogenic and (anti)androgenic activities of Tropaeolum majus L. and its effect on uterine contractility. J Ethnopharmacol. 2012;141(1):418-23. http://dx.doi.org/10.1016/j.jep.2012.03.004. PMid:22433534.

Paschoal LR, Vilela APO, Prado MRD, Ferreira WA. Aplicação do método da espectrofotometria de derivadas na identificação e doseamento simultâneo de sistemas multicomponentes. Braz J Pharm Sci. 2003;39(1):105-13.

Pavia DL, Lampian GM, Kriz GS, Vyvyan JR. Introdução a espectroscopia. São Paulo: Cengage Learning; 2010. $700 \mathrm{p}$.

Proença KS, Oliveira RVM, Gonçalves MM, Vila MMDC. Spectrophotometric method to quantitative ketoconazol analysis in shampoos. Rev. Bras. Farm. 2007; 88(4):187-190.

Razavi SM, Nazemiyeh H, Hajiboland R, Kumarasamy Y, Delazar A, Nahar L, Sarker SD. Coumarins from the aerial parts of Prangos uloptera (Apiaceae). Rev Bras Farmacogn. 2008;18(1):1-5. http://dx.doi.org/10.1590/S0102-695X2008000100002.

Rubim AM, Santos MR, Laporta LV, Rubenick JB, Santos TS. Validação de metodologia por UV / VIS para quantificação de cetoconazol em comprimidos. Rev Bras Farm. 2012;93(4):510-4.

Silva PG, Oliveira AKM, Matias R, Pedrinho DR. Germination and initial growth of nasturtium in different cultivation conditions. Rev. Bras. Agro. 2018;13(5):239-46.

Silva SCDS, Alves MA, De Sousa SA, Nogueira JRDS, Martins DHN, Fonseca-Bazzo YM, Galdos-Riveros AC. Perfil fitoquímico, susceptibilidade antibacteriana e capacidade antioxidante das folhas de Croton 
urucurana Baillon (Euphorbiaceae). Infarma. 2017;29(3):264-70. http://dx.doi.org/10.14450/23189312.v29.e3.a2017.pp264-270.

Silverstein RM, Webster FX, Kiemle DJ. Identificação espectrométrica de compostos orgânicos. 7. ed. Rio de Janeiro: LTC; 2006. 790 p.

Simões CMO, Schenkel EP, Mello JCP, Mentz LA, Petrovick PR. Farmacognosia: do produto natural ao medicamento. Porto Alegre: Artmed; 2017.

Staub I, Cruz AS, Pinto TJA, Schapoval EES, Bergold AM. Determinação da segurança biológica do xampu de cetoconazol: teste de irritação ocular e avaliação do potencial de citotoxicidade in vitro. Rev Bras. Cie Farm. 2007;43(2):301-7. http://dx.doi.org/10.1590/S1516-93322007000200017.

Staub I. Avaliação da fotoestabilidade do cetoconazol e determinação da atividade antifúngica e da segurança biológica in vivo e in vitro do xampu de cetoconazol [tese]. Porto Alegre: Faculdade de Farmácia, Universidade Federal do Rio Grande do Sul; 2005.

Valsalam S, Agastian P, Arasu MV, Al-Dhabi NA, Ghilan AM, Kaviyarasu K, Ravindran B, Chang SW, Arokiyaraj $S$. Rapid biosynthesis and characterization of silver nanoparticles from the leaf extract of Tropaeolum majus $L$. and its enhanced in-vitro antibacterial, antifungal, antioxidant and anticancer properties. J Photochem Photobiol B. 2019;191:65-74. http://dx.doi.org/10.1016/j.jphotobiol.2018.12.010. PMid:30594044.

Wu MJ, O'Doherty PJ, Fernandez HR, Lyons V, Rogers PJ, Dawes IW, Higgins VJ. An antioxidant screening assay based on oxidant-induced growth arrest in Saccharomyces cerevisiae. FEMS Yeast Res. 2011;11(4):379-87. http://dx.doi.org/10.1111/j.1567-1364.2011.00726.x. PMid:21375688.

\section{Authors' contributions}

AMS meet all four criteria for authorship; LMS meet all four criteria for authorship 